\title{
Balancing the Principle of Permanent Sovereignty over Natural Resources and Sustainable Forest Management: Indonesian Experiences*
}

\author{
Sri Wartini**
}

Most scholars argue that the principle of permanent sovereignty over natural resources (PSNR) has been used by developing countries as a legal basis to exploit their natural resources, including forests, for the sake of economic development. Land conversion and forest burning are the primary causes of forest degradation and deforestation in Indonesia. Thus, the biodiversity of Indonesian tropical forests is decreasing tremendously. This article aims to comprehensively analyze the experiences of the Indonesian government to balance the principle of PSNR and sustainable forest management (SFM). The paper argues that the implementation of the PSNR principle in SFM faces many challenges, such as deforestation, forest degradation, and the failures in implementing laws, as well as weak law enforcement. Therefore, to balance the PSNR principle with SFM, the Indonesian government needs to undertake various efforts, such as strengthening law enforcement, carrying out social forest management, and exercising mandatory forest certification. Moreover, all these efforts need to be further improved.

\footnotetext{
* The research and publication are supported by an individual research grant from the Faculty of Law at Universitas Islam Indonesia. Contact Number: +62-274-379178/Email: fh@uii.ac.id. The author would like to extend deep gratitude to Christopher M. Cason, a lecturer of Faculty of Law, Universitas Islam Indonesia for his valuable comments on the earlier version of this paper.

** Associate Professor of International Law at Faculty of Law of Universitas Islam Indonesia. S.H. (U. Gadjahmada, Yogyakarta); M.Hum (U. Padjadjaran, Bandung), Ph.D. (International Islamic University Malaysia: IIUM). ORCID: https://orcid.org/0000-0003-0781-4819. The author may be contacted at: sri.wartini@uii.ac.id/Address: Faculty of Law, Universitas Islam Indonesia, Jalan Tamansiswa,158, Yogyakarata, 55153, Indonesia.

All the websites cited in this article were last visited on October 23, 2021.
} 


\section{Keywords}

Balancing, Deforestation, Forest Degradation, Permanent Sovereignty

over Natural Resources, Sustainable Forest Management

\section{Introduction}

Forests are very important both for humans and the environment. They are natural resource that has economic, social, and ecological functions. ${ }^{1}$ However, the massive exploitation of forests ${ }^{2}$ in developing countries does significant harm the ecological and social function of the forests. The adoption of the permanent sovereignty over natural resources (PSNR) principle in most developing countries has led to the exploitation of forests in favour of their own policies and interest. PSNR is a fundamental principle of international $\operatorname{law}^{3}$ as a consequence of a people's right to self-determination. Thus, the PSNR principle is an indispensable and integral element of state sovereignty. It authorizes states to utilize and even exploit resources found within the limits of their national jurisdiction without intervention from other states. ${ }^{4}$

Deforestation and forest degradation in Indonesian tropical areas are increasing rapidly due to wild fires, illegal logging, and massive conversion for palm plantations. ${ }^{5}$ Weak law enforcement and an ineffective forest management system lead to the Indonesian government's failures in preventing and mitigating deforestation and forest degradation. ${ }^{6}$ Indeed, Indonesia is a member of various

1 Lin Feng \& G. Charltona, Balancing Biodiversity and Natural Resource Protection Objective with Ethnic Minority Autonomy: A Chinese Model, 43 Fordham InT'L L.J. 580-1 (2020), https://ir.lawnet.fordham.edu/cgi/viewcontent. cgi?article=2776\&context=ilj. See also T. Bjärstig \& S. Anna, Social Values of Forests and Production of New Goods and Services: The Views of Swedish Family Forest Owners, 17 Small-sCale Forestry 142-3 (2018), https://link. springer.com/content/pdf/10.1007/s11842-017-9379-9.pdf.

2 Hans N. Jong, Obstacles Abound in Bid to Protect Indonesia's Forests and Cut Emissions, MongaBAy, Apr. 22, 2020, https://news.mongabay.com/2020/04/obstacles-abound-in-bid-to-protect-indonesias-forests-and-cut-emis.

3 A. Daniel, Paradise Lost: Sovereign State Interest, Global Resource Exploitation and the Politics of Human Rights, 27 Eur. J. InT’L L. 673-4 (2016), https://doi.org/10.1093/ejil/chw033.

4 F. Martha, Prison or Precaution: Unilateral, State-Mandated Geoengineering under Principles of International Environmental Law, 24 N.Y.U. EnVTL. L. J. 267-8 (2016), https://www.nyuelj.org/wp-content/uploads/2016/09/ nye_24-2-Fitzgerald.pdf.

5 A. Wijaya et al., 6 Years after Moratorium, Satellite Data Shows Indonesia's Tropical Forests Remain Threatened, World Resources Institute (May 24, 2017), https://www.wri.org/blog/2017/05/6-years-after-moratorium-satellite-datashows-indonesia-s-tropical-forests-remain.

6 FAO, Indonesia Forestry Outlook Study 40 (Asia-Pacific Forestry Sector Outlook Study II Working Paper No. APFSOS II/WP/2009/13, 2009), http://www.fao.org/3/am608e/am608e00.pdf. See also Mas Achmad Santosa et al., The Progress on Governing REDD+ in Indonesia, INT'L J. RuRAL L. \& PoL'y 2 (July 2013), https://doi.org/10.5130/ 
international agreements and has various obligations to maintain the biodiversity of its forests. One of its international obligations is to enhance forest management, such as by implementing sustainable forest management (SFM). However, it is challenging to materialize and improve forest management in Indonesia because of the multifaceted social, political, and economic system. ${ }^{7}$ Forests are important for all human communities, especially due to their ability to maintain biodiversity, absorb carbon, and release oxygen, in addition to supporting the lives of the peoples who live in and adjacent to forests. ${ }^{8}$

Indonesian tropical forests have the third largest tropical forest area in the globe, ${ }^{9}$ which has rich biodiversity. Some nations, such as Indonesia, Ecuador, Brazil, and Kenya, have already included in their constitutions provisions requiring that their natural resources be utilized sustainably. ${ }^{10}$ In reality, however, most states do not exploit their forests in a sustainable manner. ${ }^{11}$ SFM is a point of concern for business authors, states, and international organizations to participate in its implementation, which is regulated in the Forest Principles ${ }^{12}$ and the 2014 New York Declaration. ${ }^{13}$ The unsustainability of the current forest management efforts is a global problem, which may affect the economic, environmental, and social interests of a state. ${ }^{14}$

The aim of this research is to comprehensively scrutinize the balancing of the PSNR principle with SFM in Indonesia, which may be deemed as the manifestation of state sovereignty. The paper consists of seven parts, including Introduction and Conclusion. It is structured as follows. Part two will discuss the genesis of the PSNR

ijrlp.i1.2013.3356.

7 A. Enrici \& K. Hubacek, Business as Usual in Indonesia: Governance Factors Effecting the Acceleration of the Deforestation Rate after the Introduction of REDD+, 1 ENERGY, ECOLOGY, ENVTL. 183 (2016), https://doi.org/10.1007/ s40974-016-0037-4, https://link.springer.com/content/pdf/10.1007\%2Fs40974-016-0037-4.pdf.

8 See Collaborative Partnership on Forests, SFM and the Multiple Functions of Forests (2012), http://www.Cpfweb. Org/32819-045ba23e53cbb67809cef3b724bef9cd0.Pdf. See also E. Hofsvang (ed.), State of the Rainforest 4 (2014), https://www.academia.edu/8421349/The_state_of_the_rainforest_2014.

9 Hans N. Jong, Indonesia Forest Assessment Casts an Optimistic Light on a Complex Issue, MongaBay, July 30, 2018, https://news.mongabay.com/2018/07/indonesia-forest-assessment-casts-an-optimistic-light-on-a-complex-issue.

10 R. Kibugi, Mainstreaming Climate Change into Public Policy Functions: Legal Options to Reinforce Sustainable Development of Kenya, 8 FlA. A \& M.U.L. Rev. 207-8 (2013), https://pdfs.semanticscholar.org/4cda/ae0ccc1a 56b22d3f541dac0bd8175d64afea.pdf.

11 B. Margono et al., Primary Forest Cover Loss in Indonesia over 2000-2012, 4 Nature Climate Change 730-5 (2014), https://www.researchgate.net/publication/282312533_Primary_forest_cover_loss_in_Indonesia_over_2000-2012.

12 Report of the United Nations Conference on Environment and Development, at 3-14 (Rio de Janeiro, June 1992), U.N. Doc. A/CONF.151/26 (vol. I) (Aug. 12, 1992), https://www.un.org/esa/documents/ga/conf151/aconf15126-1.htm.

13 New York Declaration on Forests, Climate Summit 2014, https://www.undp.org/content/dam/undp/library/ Environment\%20and\%20Energy/Forests/New\%20York\%20Declaration\%20on\%20Forests_DAA.pdf.

14 ITTO \& FAO, Forest Governance and Climate Change Mitigation, Policy Brief Prepared by ITTO and FAO (2009), at 4, http://www.fao.org/forestry/19488-0a2b1be34bcc2f24f780036ed0c5f9d69.pdf. 
principle in international law that may lead a state to utilize forests for the sake of its national interest. Part three will elaborate upon SFM at the international level, which may contribute to the state policies at the national level. The implementation of the PSNR principle in SFM in Indonesia will be examined in part four. Part five will analyse the challenges faced by the Indonesian government in implementing SFM. Part six will investigate the efforts of the Indonesian government to balance the PSNR principle and SFM. Finally, Part seven (Conclusion) will provides recommendations to enhance SFM in Indonesia and carry out further research to achieve SFM.

\section{Genesis of the PSNR Principle in International Law}

The PSNR principle began in the colonial period, when the exploitation of natural resources was controlled by colonists. ${ }^{15}$ It has become a primary principle in international law. ${ }^{16}$ The PSNR principle is applicable to not only states but also vulnerable communities, including peoples and ethnic minorities who have an interest in the resources. ${ }^{17}$ Forests are valuable for developing countries as they are a significant source of economic development. ${ }^{18}$ However, economic development often negatively impacts forest resources by means of deforestation, forest degradation, and illegal logging. Furthermore, forest exploitation to enhance economic growth may distress communities who live adjacent to forests.

Under contemporary international law, states do not have absolute sovereignty but are limited by the obligations stipulated in international treaties, ${ }^{19}$ customary international law, and general principles of law. The abundance of natural resources in most developing countries does not guarantee their economic development which

15 E. Enyew, Application of the Right to Permanent Sovereignty over Natural Resources for Indigenous Peoples: Assessment of Current Legal Developments, 8 Arctic Rev. on L. \& Pol. 228 (2017), https://www.researchgate. net/publication/321326367_Application_of_the_Right_to_Permanent_Sovereignty_over_Natural_Resources_for Indigenous_Peoples_Assessment_of_Current_Legal_Developments.

16 S. Ng'ambia, Permanent Sovereignty over Natural Resources and the Sanctity of Contracts, From the Angle of Lucrum Cessans, 12(2) Loy. U. CHI. INT'L L. Rev. 153-4 (2015), https://lawecommons.luc.edu/lucilr/vol12/iss2/3.

17 L. Miranda, The Role of International Law in Intrastate Natural Resource Allocation: Sovereignty, Human Rights, and Peoples-Based Development, 45 VAND. J. TRANSNAT'L L. 787 (2012), https://papers.ssm.com/sol3/papers.cfm?abstract $\mathrm{id}=2150275$

18 M. M'Gronigle \& L. Takeda, The Liberal Limits of Environmental Law: A Green Legal Critique, 30 PACE EnVTL. L. Rev. 1033 (2013), https://digitalcommons.pace.edu/pelr/vol30/iss3/4.

19 C. Hunter, The Submission of the Sovereign: An Examination of the Compatibility of Sovereignty and International Law, 44 Denv. J. InT'L L. \& PoL’y 534-5 (2016), https://digitalcommons.du.edu/djilp/vol44/iss4/5. 
will depend on particular circumstances, ${ }^{20}$ such as limited infrastructure, institutions, technology, and capital. Thus, the implementation of the PSNR principle does not always directly develop economy in developing countries without financial and technological assistance from developed countries to enhance the economic value of their resources.

From a legal perspective, the PSNR principle can be classified as "soft law." It was adopted in the UN General Assembly Resolution 1803 (XVII) on the "Permanent Sovereignty over Natural Resources" on December 14, 1962. ${ }^{21}$ However, a soft law may shape the formation of customary international law, if it can accomplish the two requirements to be customary international law, namely the states practice and recognize it with legal binding force (opinio jurist sive nessessitatis). ${ }^{22}$ Indeed, the PSNR principle includes a "no harm" or the maxim sic utere tuo ut alienum non laedas," 23 which determines that a state is not allowed to cause damage to other state territories ${ }^{24}$

The 1972 Stockholm Declaration ${ }^{25}$ became a benchmark and starting point for a novel conception of development. The PSNR principle was adopted in Principle 21 of the Stockholm Declaration. It stipulates as follows:

States have in accordance with the Charter of the United Nations and the principles of international law, the sovereign right to exploit their own resources pursuant to their own environmental policies, and the responsibility to ensure that activities within their jurisdiction or control do not cause damage to the environment of other States or of areas beyond the limits of national jurisdiction.

Based on Principle 21, the right of states to exploit their natural resources is limited

20 E. Paltseva \& J. Roine, Resource Curse: What Do We Know About It?, FREE Pol'y Brief Series (2011), at 1-2, https:// freepolicybriefs.org/wp-content/uploads/2011/11/free_policy_brief_paltseva_roine.pdf.

21 Permanent Sovereignty over Natural Resources, G.A. Res. 1803 (VXII), U.N. Doc. A/1803 (XVII) (Dec. 14, 1962), https://www.ohchr.org/EN/ProfessionalInterest/Pages/NaturalResources.aspx.

22 B. Chimni, Customary International Law: A Third World Perspective, 112 Aм. J. InT'L L. 3 (2018), https://www. cambridge.org/core/journals/american-journal-of-international-law/article/customary-international-law-a-third-worldperspective/DEDB6DB43A3B5A613B68FDBE56E20A20. See also R. Crootof, Change without Consent: How Customary International Law Modifies Treaties, 41 YALE J. INT'L L. 242 (2016), https://papers.ssrn.com/sol3/papers. cfm?abstract_id=2657693.

23 N. Oral, The International Law Commission and the Progressive Development and Codification of Principles of International Environmental Law, 13 FIU L. REv. 1077 (2019), https://ecollections.law.fiu.edu/lawreview/vol13/ iss $6 / 10$.

24 R. Esposito, The ICJ and the Future of Transboundary Harm Disputes: A Preliminary Analysis of the Case Concerning Aerial Herbicide Spraying (Ecuador V. Colombia), 2 PACE INT'L L. Rev. 31-2 (2010), https://digitalcommons.pace.edu/ pilronline/15.

25 Report of the United Nations Conference on the Human Environment (Stockholm, June 5-16, 1972), U.N. Doc. A/ Cnf.48/14/Rev.1, http://www.un-documents.net/aconf48-14r1.pdf. 
by the state responsibility principle. ${ }^{26}$ States are responsible for the damages they cause in other states or areas beyond the limit of national jurisdiction, such as the high seas and outer space. ${ }^{27}$ As such, the exploitation of forests as one of the resources in a certain state may cause disadvantages to other states. ${ }^{28}$ As a result, there should be a balance between the right to exercise the PSNR principle and the international obligation to conserve forests in a sustainable manner as part of the biodiversity, which is stipulated in the 1992 Biological Diversity Convention. ${ }^{29}$

\section{The Legal Framework of SMF at the International Level}

There are no legally binding agreements concerning SFM in international law, ${ }^{30}$ because forests are resources within the jurisdiction of a state. Thus, since a state has sovereignty over its natural resources, it may exploit its forests for the sake of its own interests and policy. ${ }^{31}$ Both developed and developing countries have not yet reached a legally binding agreement on SFM. The group of developed countries such as the members of the European Union would like to conserve the tropical forests in the developing countries as they act as a carbon sink that mitigates climate change. ${ }^{32} \mathrm{On}$ the other hand, the developing countries would rather prefer to utilize the forests to

26 D.Takacs, Forest Carbon (Redd+), Repairing International Trust, and Reciprocal Contractual Sovereignty, 37 VT. L. REv. 707 (2013), https://repository.uchastings.edu/faculty_scholarship/1262.

27 C. Payne, New Law for the High Seas, 37 Berkeley J. InT'L L. 355-6 (2019), https://lawcat.berkeley.edu/ record/1128936.

28 J. Rutledge, Wait A Second-Is That Rain or Herbicide? The ICJ's Potential Analysis in Aerial Herbicide Spraying and an Epic Choice Between the Environment and Human Rights, 46 WAKE Forest L. Rev. 1085 (2011), http://www. wakeforestlawreview.com/2012/02/comment-wait-a-second-is-that-rain-or-herbicide-the-icjs-potential-analysis-inaerial-herbicide-spraying-and-an-epic-choice-between-the-environment-and-human-rights.

29 H. Van Asselt, Managing the Fragmentation of International Environmental Law: Forests at the Intersection of the Climate and Biodiversity Regimes, 44 N.Y.U. J. INT'L L. \& PoL. 1224-5 (2012), https://papers.ssrn.com/sol3/ papers.cfm?abstract_id $=1703186$.

30 E. Hope, A Lack of International Agreement over the Protection of Forests: How Nations Have Risen to the Challenge of Forest Management, 29 J. EnvtL. L. \& Litig. 247 (2014), https://scholarsbank.uoregon.edu/xmlui/handle/ $1794 / 17846$.

31 R. Pereira \& O. Gough, Permanent Sovereignty over Natural Resources in the 21st Century: Natural Resource Governance and the Right to Self-Determination of Indigenous Peoples under International Law, 14 MelB. J. INT'L L. 457 (2013), https://papers.ssrn.com/sol3/papers.cfm?abstract_id=3656492.

32 A. Long, Global Climate Governance to Enhance Biodiversity and Well-Being: Integrating Non-State Networks and Public International Law in Tropical Forests, 41 ENVTL. L. 97 (2011), https://papers.ssrn.com/sol3/papers.cfm?abstract $\mathrm{id}=1694859$. See also J. Endres, Barking up the Wrong Tree? Forest Sustainability in the Wake of Emerging Bioenergy Policies, 37 VT. L. Rev. 807 (2013), https://papers.ssrn.com/sol3/papers.cfm?abstract_id=2197386. 
enhance their economic development. Therefore, the implementation of SFM at the international level depends on the practices of individual states and their awareness of the need to protect forests as shared resources.

There are various definitions of SFM, but the meaning of the term lacks uniformity in an international level. Each international organization has developed its own definition of SFM. Nonetheless, the definition of SFM according to the Resolution General Guidelines for the Sustainable Management of Forests in Europe in $1993^{33}$ is quite similar to that proposed by the UN Food and Agriculture Organisation (FAO)'s Forest Principles, which is as follows:

It is the stewardship and use of forests and forest lands in a way, an at a rate, that maintains their biological diversity, productivity, regeneration capacity, vitality and their potential to fulfil, now and in the future, relevant ecological economic and social functions, at local, national and global levels, and that does not cause damage on other ecosystems. ${ }^{34}$

According to this definition, there is no prohibition against exploiting forests, but it rather mandates stewardship to sustainably manage forests to maintain biological diversity for the interests of the present and future generations. ${ }^{35}$ SFM becomes the guideline to be followed by all states at the national level because forests are within the national jurisdiction of a state. It is therefore important to balance the utilization of forests based on its ecological, economic, and social functions for its sustainability. ${ }^{36}$ All states that have forests should introduce and implement a national policy aimed at achieving SFM. Thus, SFM needs legal instruments both internationally and nationally. In relation to the PSNR principle, SFM tends to balance the rights and obligations of states to sustain forests as one of their natural resources. SFM requires states to use forest resources in a balanced manner among

33 Second Ministerial Conference on the Protection of Forests in Europe, Resolution H1, General Guidelines for the Sustainable Management of Forests in Europe (1993), https://www.foresteurope.org/docs/MC/MC_helsinki resolutionH1.pdf.

34 Id.

35 Woong Kyu Sung, Core Issues in International Sustainable Development: Analysis of Shifting Priorities at U.N. Environmental Conferences, 44 Envtl. L. Rep. News \& Analysis 10579 (2014), https://elr.info/news-analysis/ 44/10574/core-issues-international-sustainable-development-analysis-shifting-priorities-un-environmental-conferenc. See also E. Weiss, In Fairness to Future Generations and Sustainable Development, 8 Am. U. InT'L L. Rev. 22-3 (1992), https://digitalcommons.wcl.american.edu/cgi/viewcontent.cgi?article=1498\&context=auilr.

36 N. Bryner, Public Interests and Private Land: The Ecological Function of Property in Brazil, 34 VA. EnVTL. L. J. 127-8 (2016), https://papers.ssrn.com/sol3/papers.cfm?abstract_id=3231052. See also N. Perkins, The Dialects and Dimensions of Sustainability, 21 J. EnvtL. \& Sustainability L. 337 (2015), https://scholarship.law.missouri.edu/jesl/ vol $21 /$ iss $2 / 3$. 
the economic, environmental, and social interests. ${ }^{37}$ Commonly, the economic interest becomes the priority of a state, which makes it difficult to implement the norm of sustainable development. ${ }^{38}$

\section{The Implementation of the PSNR Principle in SFM in Indonesia}

The adoption of the PSNR principle in Indonesia can be traced back to the 1945 Indonesian Constitution. Article 33(3) of the Indonesian Constitution states: "The land, the waters and the natural resources within shall be under the powers of the State and shall be used to the greatest benefit of the people." This provision has been invoked as constitutional foundation to justify logging activities in Indonesia and constitutional justification to grant license concessions. To involve the local community in SFM, the Indonesian government has already made many changes to the land allocation and tenure system, particularly related to forests. The Constitutional Court Decision Number 35/PUU-X/2012 proclaimed in 2013 was a historic milestone recognizing indigenous people's rights over their traditional forests. ${ }^{39}$

All resources in Indonesia are under the control of the Indonesian government. However, the implementation of the PSNR principle does not solely belong to the state, but also to civic society including individual and indigenous people who enjoy the resources. ${ }^{40}$ The principle leads sovereign states to use resources for the well-being of all their citizens. Viewing the utilization of forests as a part of the state's natural resources is important to ensure that SFM will be embodied in the forest management in Indonesia. In this sense, Article 33(3) of the Indonesian Constitution allows the government to utilize all natural resources to enhance citizens' welfare. The provision reflects the political will of Indonesia in managing and utilizing its resources. Article

37 M. Nieuwenhuis \& T. Dermot, The Impact of the Introduction of Sustainable Forest Management Objectives on the Optimization of PC-Based Forest-Level Harvest Schedules, 7(4) Forest PoL'y \& ECON. 689 (2005), https://www. researchgate.net/publication/223580981_The_impact_of_the_introduction_of_sustainable_forest_management objectives_on_the_optimisation_of_PC-based_forest-level_harvest_schedule.

38 V. Barral, Sustainable Development in International Law: Nature and Operation of an Evolutive Legal Norm, 23(2) Eur. J. INT'L L. 383-5 (2012), http://www.ejil.org/article.php?article=2292\&issue=111.

39 Agni K. Boedhihartono, Can Community Forests Be Compatible with Biodiversity Conservation in Indonesia?, 6 LAND 1 (2017), https://www.mdpi.com/2073-445X/6/1/21.

40 D. Cambou \& S. Smis, Permanent Sovereignty over Natural Resources from a Human Rights Perspective: Natural Resources Exploitation and Indigenous Peoples' Rights in the Arctic, 22 Мich. ST. INT'L L. Rev. 360-1 (2013), https:// papers.ssrn.com/sol3/papers.cfm?abstract_id=2378709. 
33(3) obliges the state to guarantee that the use of resources is aimed at the benefit of all its people. In addition, the phrase "controlled by state" ${ }^{" 41}$ means that the state has the authority to regulate and control all natural resources within its jurisdiction to enhance the prosperity of the Indonesian people. The Constitutional Court explains: "The term 'regulating' means the authority to legislate and implement laws, regulations and policies." $"$

To implement Article 33(3) of the Indonesian Constitution, the Indonesian government issued a framework for managing land and natural resources both modern law and customary tenure system in the Law Number 5 Year 1960 and Law Number 5 Year 1967 concerning Basic Agrarian Law and Basic Forestry Law, respectively. ${ }^{43}$ However, the Agrarian Law causes conflicts between the government and indigenous people. ${ }^{44}$ Indonesia has officially been exploiting forests since 1967, when the government enacted Law Number 5 Year 1967 concerning Basic Forestry Law. ${ }^{45}$ However, the law violated indigenous people's rights due to the recognition of private ownership, which conflicted with their rights to the land. ${ }^{46}$

In 1999, the Indonesian government introduced a new forestry law, namely Law Number 41 Year 1999 concerning Forestry, which amended Law Number 5 Year 1967 regarding Basic Forestry Law. ${ }^{47}$ However, on October 5, 2020, Indonesia issued Law Number 11 Year 2020 concerning the Job Creation Law (Omnibus Law) that amended and revoked several provisions of 76 laws; $^{48}$ three of them were Law Number 32 Year 2009 related to Environmental Protection and Management, Law Number 41 Year 1999 concerning Forestry, and Law Number 22 dealing with Autonomy, which was amended by Law Number 32 Year 2004 related to Regional Administration and was in turn amended by Law Number 23 Year 2014 concerning Local Government.

41 Eko P. Purnomo \& P. Anand, The Conflict of Forest Tenure and the Emergence of Community Based Forest Management in Indonesia, 5(1) J. Stud. Pemerintahan 21 (2014), http://dx.doi.org/10.18196/jgp.2014.0003.

42 F. Siregar \& S. Butt, State Control over Natural Resources in Indonesia: Implications of the Oil and Natural Gas Law Case of 2012, 31 J. EnERgy \& NAt. Res. L. 111 (2013), https://www.researchgate.net/publication/279163019_State_ Control_over_Natural_Resources_in_Indonesia_Implications_of_the_Oil_and_Natural_Gas_Law_Case_of_2012.

43 A. Rossabi, Legal Policies Surrounding the Degradation of Indonesia's Forests, 1 Res. Communes 36 (1999), https:// irp-cdn.multiscreensite.com/ee52edf5/files/uploaded/Legal-Policies-Surrounding-the-Degradation-of-IndonesiasForests.pdf.

44 R. Riggs, Forest Tenure and Conflict in Indonesia: Contested Rights in Rempek Village, Lombok, 57 LAND USE PoL'Y 242 (2016), https://www.academia.edu/33975615/Forest_tenure_and_conflict_in_Indonesia_Contested_rights_in_ Rempek_Village_Lombok.

45 Id.

46 Rossabi, supra note 43, at 37.

47 FAO, supra note 6.

48 K. Molina \& F. Ramadhan, Omnibus Law and Its Implementing Regulations, White \& Case (2021), https://www. whitecase.com/publications/alert/omnibus-law-and-its-implementing-regulations. 
The Job Creation Law simplifies licensing requirements and procedures. Previously, under the Basic Forestry Law, numerous licenses were required for the utilization of protected and production forests such as environmental services utilization permit, forest area utilization permit, non-timber/timber forest product collection permit, and non-timber/timber forest product utilization permit. ${ }^{49}$ The facilitation of license procedures may affect the implementation of SFM in Indonesia because the Job Creation Law integrates all of the aforementioned licenses into a business license granted by the central government for individuals or corporations seeking license to use protected and production forest. ${ }^{50}$ It is questionable whether each license will cover many forest utilization activities. Furthermore, the environmental permit as one of the requirements to obtain an operation permit based on Law Number 32 Year 2009 regarding Environmental Protection and Management has been abolished. ${ }^{51}$ This may cause massive forest degradation.

Indeed, not all the provisions of Law Number 41 Year 1999 were changed with introduction of the Job Creation Law's provisions. Thus, the rest of the article remains in effect. Forest management in Indonesia is regulated by Article 3 of Law Number 41 Year 1999 concerning Forestry, which states as follows:

Forest management shall be aimed at providing maximum prosperity for the people based on justice and sustainability by: (a) securing existence of forest at adequate extent and proportional distribution; (b) optimising various forest functions covering conservation, protection, and production functions to attain environmental, social, cultural and economic benefits proportionally and sustainably; (c) increasing baring capacity of river sheds; (d) increasing capability to develop community's capacity and capability on participation, justice, and sustainability basis to create social and economic resilience as well as endurance against impacts of external changes; and (e) securing distribution of benefits on just and sustainability basis.

According to Article 3 of Law Number 41 Year 1999 concerning Forestry, the Indonesian government has various obligations, such as the duty to ensure the existence of its forests and the distribution of forest assets for state, businesses, and the indigenous people who live along forest borders. Furthermore, the Indonesian

\footnotetext{
49 Indonesia: Omnibus Law-Impacts on Environment and Forestry, Baker \& McKenzie (Oct. 9, 2020), https://insightplus. bakermckenzie.com/bm/environment-climate-change_1/indonesia-omnibus-law-impacts-on-environment-andforestry\#cntAnchor3.

50 Id.

51 R. Sembiring et al., Indonesia's Omnibus Bill on Job Creation: a Setback for Environmental Law?, 4 CHINESE J. ENVTL. L. 99 (2020).
} 
government is also obliged to enhance the capacity of the community to participate in forest management as well as to optimize the various functions of the forest. ${ }^{52}$

SFM should enable local communities to perform significant roles in forest management. The community-based approach is adopted "in response to the shift in the management approach, from timber-based management to forest-resource management." ${ }^{, 53}$ The outline to achieve SFM in Indonesia is contained in the following five Program Areas, which are stipulated in the Agenda 21 Indonesia, namely:

(1) Developing and sustaining integrated sustainable forest production;

(2) enhancing the regeneration, rehabilitation and protection of forests; (3) strengthening regulations and law enforcement for sustainable forest management; (4) maintaining and improving the participation and welfare of forest-dwelling communities; (5) establishing and strengthening research and capacity in sustainable forest management. ${ }^{54}$

Based on the five objectives of Agenda $21{ }^{55}$ the Indonesian government is aware that forests are important for the sustenance of the environment and humans.

The Indonesian government has a series of strong political and economic measures in place to meet the obligations stipulated in various international instruments, including the Forest Principles. However, the legal instruments that have been issued by the Indonesian government face many challenges, such as the lack of participation by the business sector and communities who live nearby the forests. Hence, inter-sectorial dialogues involving the government and the various stakeholders need to be established in order to achieve SFM.

The implementation of SFM is regulated in Article 4 Law Number 41 Year 1999 concerning Forests. Based on this provision, Indonesia is obliged to control the management of the forests, namely:

1. All forests in territory of the Republic of Indonesia including natural resources contained therein shall be controlled by state for the maximum prosperity of the

52 M. Siscawati \& R. Zakaria, Capacity Building Needs Assessment for Community Forestry in Indonesia, Final Full Report for the Center for People and Forests (2010), https://www.academia.edu/30778806/Capacity_Building_Needs_ Assessment_for_Community_Forestry_in_Indonesia_RECOFTC_The_Center_for_People_and Forests.

53 Ani Adi Winata Nawir et al., Forest Rehabilitation in Indonesia: Where to After More Than Three Decades? 114 (2007), http://www.cifor.org/publications/pdf files/Books/BNawir0701.pdf.

54 The UN Commission on Sustainable Development, Natural Resource Aspects of Sustainable Development in Indonesia (5th Sess. 1997).

55 UNCED, AGENDA 21 (June 3-14, 1992), https://sustainabledevelopment.un.org/content/documents/Agenda21.pdf. See also US Environmental Protection Agency, Products of the 1992 Earth Summit (1993), https://archive.epa.gov/epa/ aboutepa/products-1992-earth-summit.html. 
people;

2. Forest control by the state as referred to in Paragraph 1 shall mean authority of the government to: (a) maintain and manage anything relating to forest, forest area, and forest products; (b) stipulate certain area status as forest area or forest area and non-forest area; and (c) maintain and stipulate legal relations of people to forests as well as legal acts concerning forestry; and

3. Forest control by state shall remain, taking into account rights of law community if any, and its existence is acknowledged and not contradictory to national interests.

Thus, the central government has the authority to determine which areas shall be designated forest protected and non-forest protected. However, the Job Creation Law affects the license system in the forestry sector. All licenses are centralized to the government, while before the enactment of the Job Creation Law, the license procedure in the forestry sector was decentralized to the province and district level. This decentralization aimed to empower local communities to actively participate in forest management. ${ }^{56}$

Furthermore, Article 6(2) of Law Number 41 Year 1999 concerning Forest stipulates that the state divide the forest estate into three categories, based on its main functions, namely: (a) Conservation Forests: for the conservation of plant and animal species; (b) Protection Forests: for serving life support systems and regulating services provided by forests; and (c) Production Forests: for producing forest products. The classification of forests into three categories indicates that the Indonesian government is managing its forests in a sustainable manner.

\section{The Challenges Facing the Indonesian Government in Implementing SFM}

The Indonesian government faces many challenges in achieving SFM. Four major challenges are deforestation, forest degradation, the failure in implementing regulations, and weak law enforcement. The sustainable development principle has been integrated into SFM to create a norm to balance economic development,

56 A. Yakin \& J. Othman, Forest Resources and Policy in the Age of Regional Autonomy in Indonesia, Proc. International Seminar on "Sustainable Economic, Business, and Social Development in an Era of Globalization" (Oct. 2003), https://www.researchgate.net/publication/319804642_Forest_Resources_and_Policy_in_the_Age_of_ Regional_Autonomy_in_Indonesia_1. 
social development, and environmental protection, ${ }^{57}$ rather than being solely exploitation-oriented. Thus, the exploitation of forests in Indonesia to enhance economic development has to be integrated with environmental protection and social development. These four challenges to realizing SFM therefore need to be addressed.

\section{A. Deforestation and Forest Degradation}

Two of the challenges to implementing SFM in Indonesia are deforestation and forest degradation. Before questioning why deforestation and forest degradation have become the major obstacles to actualize SFM in Indonesia, it is important to understand their definition. One of the definitions of deforestation and forest degradation may be referred to in the Accountability Framework Initiative (AFI) which established the concept of deforestation comprehensively. The AFI defines deforestation as the "loss of natural forest as a result of: (i) conversion to agriculture or other non-forest land use; (ii) conversion to a tree plantation; or (iii) severe and sustained degradation." 58 This definition includes land conversion or concessions based on licenses or concessions issued by the government. The definition of forest degradation is narrower than deforestation. It occurs "when forest ecosystems lose their capacity to provide important goods and services to people and nature"59 regardless of whether there is land conversion.

Deforestation and forest degradation cause damage to the ecosystem so that the forests lose their ecological capabilities, such as to absorb and store carbon and to preserve water. ${ }^{60}$ The trigger for deforestation and forest degradation are land conversions from forests to plantation areas, such as palm and rubber plantations, as well as due to logging activities. ${ }^{61}$ Moreover, deforestation and forest degradation in Indonesia are worsened by forest fires, whether naturally caused or otherwise by individuals or even companies. ${ }^{62}$ Due to forest fires, biodiversity decreases

57 E. Hush, Where No Man Has Gone Before: The Future of Sustainable Development in the Comprehensive Economic and Trade Agreement and New Generation Free Trade Agreements, 43 Colum. J. EnvtL. L. 101-2 (2018), https:// papers.ssrn.com/sol3/papers.cfm?abstract_id=3373398.

58 H. Resnick, Seeing the Forest for the Trees: Public and Private Law Tools for Halting Deforestation, 37 PACE EnvtL. L. Rev. 6-7 (2019), https://digitalcommons.pace.edu/pelr/vol37/iss1/1.

59 Id.

60 Green Facts, Valuing the Ecosystem of the Indonesian Rainforest (2015), http://www.greenfacts.org/en/indonesianforests/index.htm.

61 K. Austin et al., What Causes Deforestation in Indonesia?, 14 EnvtL. Res. LetTERs 5 (2019), https://iopscience.iop.org/ article/10.1088/1748-9326/aaf6db/pdf.

62 Md Badri et al., The Viewpoint of Stakeholders on the Causes of Forest and Land Fires in Riau Province, Indonesia, 74(2) Russian J. Agricultural \& Socio-Econ. Sci. 7-8 (2018), https://www.academia.edu/44912929/THE_ VIEWPOINT_OF_STAKEHOLDERS_ON_THE_CAUSES_OF_FOREST_AND_LAND_FIRES_IN_RIAU_ 
tremendously. Besides, it results in economic losses and affects human health. "The forest fires in Indonesia in 2015 released almost twice as many greenhouse gases as Germany emitted in 2014."

Indonesia's rainforests have been severely damaged and diminished due to logging as well as forest fires. ${ }^{64}$ According to the Report of the Indonesian Ministry of Forestry "almost 0.4 million hectares were disappeared between 2009 and 2011."65 Reports of deforestation in Indonesia are very important as a data that can be used to improve forest management effectively. Combating and mitigating forest degradation and deforestation remains a serious imperative that needs to be addressed. Ironically, forest burning in Sumatra and Borneo occur because of slash burning carried out by private companies whose majority of shares are owned by foreign investors from Malaysia. ${ }^{66}$

\section{B. The Failures in Implementing Laws and Regulations to Embody SFM}

Decentralization may aim to empower and enhance local communities to manage forests in a sustainable manner. It has caused deforestation and forest degradation due to the district governments' lack of awareness to manage forests sustainably. ${ }^{67}$ The impact of palm oil production on deforestation and forest degradation can be proven by the extent of land conversion that has been permitted by the district governments during the decentralization era. ${ }^{68}$ In addition, a significant conflict concerning the clarity of land tenure rights and ownership has become one of the factors that has been initiating unsustainable forest management ${ }^{69}$ and affecting the

PROVINCE.

63 P. Hirschberger, Forests Ablaze Causes and Effects of Global Forest Fires, WWF STudy 83 (2017), https://mobil. wwf.de/fileadmin/fm-wwf/Publikationen-PDF/WWF-Study-Forests-Ablaze.pdf.

64 H. Purnomo et al., Forest and Land Fires, Toxic Haze and Local Politics in Indonesia, 21(4) InT'L Forestry Rev. 3-4 (2019), https://www.cifor.org/publications/pdf_files/articles/APurnomo1902.pdf.

65 Margono et al., supra note 11.

66 Sahabat Alam Malaysia, Malaysian Overseas Foreign Direct Investment in Oil Palm Land Bank: Scale and Sustainability Impact (2014), at 7, https://foe-malaysia.org/wp-content/uploads/2020/12/140617_3093_SAM_ OFDI_17_June_2014_Final.pdf.

67 A. Suwarno et al., Governance, Decentralization and Deforestation: The Case of Central Kalimantan Province, Indonesia, 54(1) Q. J. INT'L AGriculture 87-8 (2015), https://www.researchgate.net/publication/280918279 Governance_Decentralisation_and_Deforestation_The_Case_of_Central_Kalimantan_Province_Indonesia.

68 Vid Adrison, Deforestation in Decentralized and Democratic Indonesia 2-3 (LPEM-FEUI Working Paper, 2013), https://www.lpem.org/wp-content/uploads/2014/09/WP_2014.pdf.

69 M. Litvinoff \& T. Griffiths (eds.), Securing Forests Securing Rights Report of the International Workshop on Deforestation and the Rights of Forest Peoples 21-2 (2014), http://www.forestpeoples.org/sites/fpp/files/private/ publication/2014/09/prreport.pdf. 
unsuccessful implementation of laws in Indonesia.

Indonesia has enacted several regulations to control and prohibit the open burning. These regulations are, however, ambiguously and ineffectively enforced ${ }^{70}$ and suffer from budgetary and resources matter. ${ }^{71}$ Indeed, the Job Creation Law maintains Article 69 (1)(h) of Law Number 32 Year 2009 on Environmental Protection and Management. It states: "Any person is prohibited from clearing land by the way of burning." However, the Job Creation Law removed the exemption to prohibition for burning by traditional farmers with a total area of 2 hectares at maximum per household to be planted with local variety and be surrounded by firebreaks "in the forest."72 The removal of Article 69, paragraph (2) will potentially result in the criminalization of traditional farmers. ${ }^{73}$ This regulation is in contradiction with SFM since the situation and condition of forest is vulnerable as especially affected by the El Niño weather pattern.

Actually, the forest fires in Kalimantan and Sumatra in 2015 during the dry season from around June through September caused serious impact to human health, which even reached the territories of Singapore and Malaysia and caused disadvantages to both states. ${ }^{74}$ According to the World Bank, Indonesia had to spend a huge money to overcome the forest fire. ${ }^{75}$

Due to corruption, the regulations are not well enforced, and the monitoring of companies and farmers is insufficient. ${ }^{76}$ It has been argued that logging and

70 L. Nurhidayah, Legislation, Regulations, and Policies in Indonesia Relevant to Addressing Land/Forest Fires and Transboundary Haze Pollution: A Critical Evaluation, 16 Asia PAC. J. ENvtL. L. 238 (2013), https://www.researchgate. net/publication/283737237_Legislation_regulations_and_policies_in_Indonesia_relevant_to_addressing_landforest_ fires_and_transboundary_haze_pollution_A_critical_evaluation.

71 Isna Fatimah, Coping with Forest and Land Fire Regulatory Challenges in Indonesia: An Assessment to The Regulatory Enforcement, 5(2) J. Vasyl Stefanyk Precarpathian NAt'l U. 207 (2018), https://scholar.google.co.id/ citations?view_op=view_citation\&hl=id\&user=wkI40nAAAAAJ\&citation_for_view=wkI40nAAAAAJ:d1gkVwhDpl $0 \mathrm{C}$.

72 Law of The Republic of Indonesia Number 32 Year 2009 Concerning Protection and Management of Environment, http://www.apbi-icma.org/uploads/files/old/2016/02/UU-No.-32-Tahun-2009.pdf.

73 R. Sembiring et al., Degradation of Environmental Protection and Management Instruments under Draft Bill on Job CREATION 12 (2020), https://icel.or.id/wp-content/uploads/DEGRADATION-OF-ENVIRONMENTALPROTECTION-AND-MANAGEMENT-INSTRUMENTS-UNDER-DRAFT-BILL-ON-JOB-CREATION-.-REV. YF_pdf.

74 A. Voiland, Seeing Through the Smoky Pall: Observations from a Grim Indonesian Fire Season, NASA Earth Observatory (Dec. 1, 2015), https://earthobservatory.nasa.gov/features/IndonesianFires. See also supra note 72.

75 C. Wright, Blueprint for Survival: A New Paradigm for International Environmental Emergencies, 29 FoRDHAM EnvTL. L. Rev. 253-4 (2017), https://ir.lawnet.fordham.edu/elr/vol29/iss2/5.

76 P. Listiningrum, Transboundary Civil Litigation for Victims of Southeast Asian Haze Pollution: Access to Justice and the Non-Discrimination Principle, 8 J. Transnat'L EnvtL. L. 124 (2018), https://www.cambridge.org/core/journals/ transnational-environmental-law/article/transboundary-civil-litigation-for-victims-of-southeast-asian-haze-pollutionaccess-to-justice-and-the-nondiscrimination-principle/C092C3C20414B93A86E86D1F8D566C3D. 
plantation companies are able to use the slash and burn method to convert large areas of forest into agricultural areas to pursue their own short-term benefits. ${ }^{77}$ As a result, deforestation in Indonesia reached 40 million cubic meters a year due to timber industries abusing logging concession from the 1970 s to $2014 .^{78}$

\section{Weak Law Enforcement}

Previously, there were numerous regulations that controlled forestry, but they did not particularly apply criminal sanctions to forestry activities. Finally, Indonesia adopted Law Number 5 Year 1990 on the conservation of living resources and their ecosystems, Law Number 41/1999 concerning forestry, and Law Number 32 Year 2009 related to environmental protection and management. These three laws define forest crimes and their associated sanctions, which include imprisonment and fines. ${ }^{79}$ Notably, there are two major aspects leading to the weak law enforcement in the forestry sector, namely the regulations and human resources. ${ }^{80}$

The weak law enforcement in the forestry sector are due to inconsistence of the laws and regulations. ${ }^{81}$ Also, there is a lack of coordination among the institutions in charge of law enforcement. Law Number 41 Year 1999 was somewhat inconsistent with the decentralisation law-Law Number 22 Year 1999 on regional administration. Indeed, there are numerous district governments that abuse their autonomy by easily granting a license for land conversion from forests to plantation area. Consequently, Law Number 22 Year 1999 was amended by Law Number 32 Year 2004 on regional administration, which was finally amended by Law Number 23 Year 2014 related to local government that withdraws the authority of the district government to grant license. Hence, the local government only has the authority to manage grand forest

77 D. Jerger Jr., Indonesia's Role in Realizing the Goals of ASEAN's Agreement on Transboundary Haze Pollution, 14 Sustainable Dev. L. \& Pol'y 36 (2014), https://digitalcommons.wcl.american.edu/cgi/viewcontent.cgi?article= $1545 \&$ context $=$ sdlp\&httpsredir $=1 \&$ referer $=$.

78 Purnomo \& Anand, supra note 41, at 27.

79 Luca Tacconi et al., Law Enforcement and Deforestation: Lessons for Indonesia from Brazil, 108 Forest POL'y \& ECON. 6 (2019), https://www.researchgate.net/publication/333683570_Law_enforcement_and_deforestation_Lessons _ for_Indonesia_from_Brazil.

80 The World Bank, Strengthening Forest Law Enforcement and Governance Addressing a Systemic Constraint to Sustainable Development Environment and Agriculture and Rural Development Addressing a Systemic Constraint to Sustainable Development, Departments Report No. 36638-GLB, 5-7 (Aug. 2006), https://documents1.worldbank.org/ curated/en/330441468161667685/pdf/366380REVISED010Forest0Law01PUBLIC1.pdf.

81 Ely Susanto et al., Driving Factors of Deforestation in Indonesia: A Case of Central Kalimantan, 9(4) J. STUDI PEMERINTAHAN 524 (2018), https:/www.researchgate.net/publication/331742991_Driving_Factors_Of_Deforestation In_Indonesia_A_Case_Of_Central_Kalimantan. 
parks. ${ }^{82}$ The centralization of authority for managing forests is strengthened in Law Number 11 Year 2020 concerning job creation.

The abuse of power by district governments still continues, but the central government is not able to cease this. ${ }^{83}$ The weak law enforcement in the forestry sector is caused by forest officials who involve in corruption, such as approving exports without legal permits and requiring bribes for obtaining a license. ${ }^{84}$ The corruption in the forestry sector is classified as organized crime. The complexity of the crime pervades across the entire production chain from forests to ports, which may include local governments, transport authorities, forest rangers, the police, and customs. Therefore, it is difficult to overcome the crime as a whole. ${ }^{85}$ More seriously, legal frameworks do not successfully protect the rights of communities and various regulations are vague. All these have contributed to the failure of law enforcement. ${ }^{86}$

\section{The Analysis of the Efforts to Balance PSNR and SFM in Indonesia}

The PSNR principle would not result in SMF in Indonesia because it mainly prioritizes economic development. Therefore, balancing PSNR and SFM is necessary. The unsuccessful management of conservation forest ${ }^{87}$ has pushed the Indonesian government to consider new strategies, policies, and regulations to protect its forests. Accordingly, the Indonesian government has already implemented some measures to achieve SFM, such as strengthening law enforcement, as well as establishing Community-Based Forest Management (CBFM) and applying forest certification.

82 Law of the Republic of Indonesia No. 23 Year 2014 about Local Government, https://www.fao.org/faolex/results/ details/en/c/LEX-FAOC160168.

83 B. Setiono \& Y. Husein, Fighting Forest Crime and Promoting Prudent Banking for Sustainable Forest Management the Anti Money Laundering Approach 5 (CIFOR Occasional Paper No. 44, 2005), http://www.cifor. org/publications/pdf_files/OccPapers/OP-44.pdf.

84 Id. See also United Nations Office on Drugs and Crime, Illegal Logging in Indonesia: The Link between Forest Crime and Corruption (2010), https://www.unodc.org/unodc/en/frontpage/2010/June/illegal-logging-in-indonesia-the-linkbetween-forest-crime-and-corruption.html.

85 Id.

86 F. Downs, Rule of Law and Environmental Justice in the Forests: The Challenge of 'Strong Law Enforcement' in Corrupt Conditions, 11 Anti-Corruption Resource Centre U4 Issue No. 6 (June 2013), https://www.cmi.no/publications/file/4834rule-of-law-and-environmental-justice-in-the.pdf.

87 N. Coca, Despite Government Pledges, Ravaging of Indonesia's Forests Continues, Yale Env't 60 (Mar. 22, 2018), https://e360.yale.edu/authors/nithin-coca. 


\section{A. Strengthening Law Enforcement}

As SFM would not be achieved without enforceable legal instruments, it is fundamental to enhance the enforcement of forestry laws. Therefore, the existing laws that regulate the protection of Indonesian forests need to be improved. To achieve SFM, the Indonesian government issued Government Regulation Number 44 Year 2004 on Forest Planning and Government Regulation Number 6 Year 2007 related to Forest Administration and Forest Management Plan. The two government regulations were issued to implement Law Number 41 Year 1999 concerning forestry. Article 2(1) of the Government Regulation Number 44 Year 2004 on Forest Planning states:

The purpose of the forestry planner is to provide guidance and direction for the government, provincial government, district/city government, community, business actors, professional institutions, which contain forestry strategies and policies to ensure the achievement of forestry objectives.

Pursuant to Article 2(1), conflict between the provincial, district, and central governments' forest planning policies can be avoided if all stakeholders fulfil their obligations and obey the guideline that has been determined by the government. Unless the conflict can be prevented, however, they have to find the solutions to achieve the forestry objective.

To enhance law enforcement for preventing deforestation and forest degradation, in 2011, the Indonesian government issued a remarkable policy, namely the Moratorium on the Utilization of Primary Natural Forests and Peatlands. ${ }^{88} \mathrm{~A}$ Presidential Instruction was issued as a legal basis to apply the moratorium. As per the instruction, the moratorium had been prolonged in 2013, 2015, and 2017 and expired on July 17, 2019. ${ }^{89}$ The Presidential Instruction Number 10 Year 2011 "aims to suspend the granting of new concession licenses for logging and conversion of forests and peatlands for two years from the date of enactment, with the suspension allowing for better planning for forest governance through the institution of necessary coordination processes, data collection and, potentially, new regulations." However, the moratorium was not successful because secondary forests were not

88 K. Austin et al., Indonesia's Forest Moratorium: Impacts and Next Steps 2 (World Resources Institute Working Paper, 2014), https://luk.staff.ugm.ac.id/rawa/WRI/indonesia-forest-moratorium-next-steps.pdf.

89 Dewi Kurniawati, President Jokowi Makes Moratorium on Forest Clearance Permanent, PALm SCRIBE, Aug. 16, 2019, https://thepalmscribe.id/president-jokowi-makes-moratorium-on-forest-clearance-permanent.

90 D. Muldiyarso et al., Indonesia's Forest Moratorium: A Stepping Stone to Better Forest Governance? 2 (CIFOR. Working Paper, 2011), https://www.cifor.org/publications/pdf_files/WPapers/WP-76Murdiyarso.pdf. 
included in it. As a result, communities as well as private companies still conducted land conversion and forest burning. This led to a sharp increase in deforestation since 2011. Based on Greenpeace's analysis, around 45,000 square kilometres (17,400 square miles) of forests and peatlands have been wiped off from the map. ${ }^{91}$

The Indonesian government has already determined which institutions are in charge of monitoring and controlling the forest areas, issuing permits, and circulating forest products. Monitoring and controlling are conducted by forest rangers, as well as the Forest Rangers Quick Response Unit, acting together with local governments, the Indonesian Armed Forces, and the Indonesian National Police, upon receiving the information from local communities or NGOs. ${ }^{92}$ Thus, it needs good coordination and cooperation among its institutions. Additionally, it is essential to supervise and monitor intensively to improve management and prevention.

The government applies three legal instruments to create strong deterrent effect such as administrative sanctions, criminal law enforcement, and civil law sanction. ${ }^{93}$ In 2015-17, the government imposed 394 administrative sanctions on the perpetrators of the 2015 catastrophic forest and land fires, which included written reprimands and the issuance of warning letters, suspension of licenses, mandatory corrective actions, and revocation of licenses. ${ }^{94}$ Meanwhile, the civil cases in this period reached 13. "Five of them were resulted in inkracht van gewijsde [defined decision] or final legally binding judgments." 95 The total penalty for compensation and restoration costs associated with environmental damage amounted to IDR 16.75 trillion or USD 1.2 billion." ${ }^{96}$ Meanwhile, the criminal cases handled by civil investigators reached 275 , and the criminal cases managed by the police, supported by the Ministry of Environment and Forestry, came to $127 .^{97}$

Accordingly, to strengthen law enforcement, ${ }^{98}$ the Indonesian government introduced Law Number 18 Year 2013 in 2013 for the prevention and eradication of forest destruction. The law has a new provision that is different from Law Number 41 Year 1999 concerning criminal sanctions. Based on Law Number 41 Year 1999

91 Hans N. Jong, Indonesian Ban on Clearing New Swaths of Forest to be Made Permanent, Mongabay, June 10, 2019, https://news.mongabay.com/2019/06/indonesian-ban-on-clearing-new-swaths-of-forest-to-be-made-permanent.

92 Ruanda Agung et al., The State of Indonesia's Forest 2018: Ministry of Environment and Forestry 39 (2018), https://www.menlhk.go.id/uploads/site/download/1540796347.pdf.

93 Greenpeace Southeast Asia, Indonesian Forest Fires Crisis: Palm Oil and Pulp Companies with Largest Burned Land Areas are Going Unpunished (Sept. 24, 2019), https://www.greenpeace.org/southeastasia/publication/3106/3106.

94 Agung ET AL., supra note 92, at 40.

95 Id. at 43.

96 Id.

$97 \quad I d$. at 42.

98 Downs, supra note 86, at 18. 
on forestry, criminal sanctions are only applicable to individuals, while, in Law Number 18 Year 2013, criminal sanctions are directly applicable to corporations. It is expected to have a greater deterrent effect on corporations that have already caused forest destruction. However, the Job Creation Law that was issued on November 2020 inserted Article 110A between Article 110 and Article 111 to amend part of Law Number 18 of 2013 on the Prevention and Eradication of Forest Destruction. Article 110 A on the Job Creation Law provides an opportunity to the business authors to continue their license which has not fulfilled the requirements to run business in the forestry sector till 3 months after the Job Creation Law was issued ${ }^{99}$ If the business authors do not comply with the law, they only get administrative sanction, there is no criminal sanction. Thus, Article 110 (A) on the Job Creation Law has weakens the sanction which is available in the Law Number 18 of 2013 on the Prevention and Eradication of Forest Destruction. Undeniably, the content of this additional provision would allow the legalization of concessions in various sectors located in forest areas, ${ }^{100}$ which may affect the implementation of SFM in Indonesia.

According to Article 54 Law Number 18 Year 2013, the Forestry Ministry, the Indonesian National Police, the Attorney General's Office, and the Corruption Eradication Commission are committed to the prevention and eradication of forest destruction and authorized to conduct a multi-door law enforcement. The multidoor approach is expected to impose the multi sanctions on the perpetrators through administrative, criminal and private law. Additionally, it aims to develop integrated law enforcement system. Thus, the multi sanction can be applicable for serious cases. ${ }^{101}$ The applicability of various laws depends on a case-by-case basis in enhancing the deterrent effect and preventing perpetrators' escape from law enforcement to achieve SFM.

Arguably, the multi-door approach has not been successfully implemented due to the lack of coordination among the institutional bodies, the lack of financial support, and administrative constraints. However, there have been some improvements. For instance, "the coordination between investigators and prosecutors is also getting stronger. The collection of evidence in the field involving investigative attorneys and prosecutors allowed the investigator to collect relevant evidence."102 Thus, the multi-door system can enhance law enforcement with good coordination among the

99 Job Creation Law Year 2020, art. 110(A).

100 Bhimanto Suwastoyo, Omnibus Law Opens the Door to Legalization of Various Concessions in Forests, Forest SCRIBE, Nov. 11, 2020, https://theforestscribe.id/omnibus-law-opens-the-door-to-legalization-of-various-concessions-in-forests.

101 Siti Nurbaya (Ed.), The State of Indonesia’s Forests 2020, 44-5 (2020), https://kemlu.go.id/oslo/en/news/10525/ e-book-the-state-of-indonesias-forests-2020.

102 Id. at 44 . 
institutional bodies in charge in the law enforcement, both vertically and horizontally.

\section{B. The Implementation of Community-Based Forest Management}

CBFM is aimed at: restoring the damage to forests; strengthening the sense of belonging to the community by providing access to state forests; ${ }^{103}$ reducing the deforestation and forest degradation; alleviating poverty; and recognizing community rights. ${ }^{104}$ The CBFM policy was developed by the central government to especially enable the community to obtain access to national forests and "transfer the state authority's over forest resources to local community,"105 as stipulated in the Ministerial Regulation Number: P.83/MENLHK/SETJEN/KUM.1/10/2016 concerning social forestry. The decentralization of power from the central government to the communities faces many challenges, such as the lacking capabilities of communities to manage forests in a sustainable manner. Besides, the process to obtain a permit is costly and may take more than two years. ${ }^{106}$ However, the government often loses its targets and only a small portion of the total area proposed for various CBMF schemes can be materialized due to budget limitations ${ }^{107}$ and the failure to empower the communities. $^{108}$

In fact, CBFM has not been successful yet due to much land conversion, illegal logging, ${ }^{109}$ and a persistent lack in building the communities' capabilities to conduct

103 L. Rumboko et al., Optimizing Community-Based Forest Management Policy in Indonesia: A Critical Review, 16(3) J. Ilmu Sosial dan Ilmu Politik [Social science \& Political Science] 255 (2013), https://media.neliti.com/media/ publications/37775-EN-optimising-community-based-forest-management-policy-in-indonesia-a-critical-revi.pdf.

104 S. Mahanty, Reducing Poverty through Community Based Forest Management in Asia, 5(1) J. Forest \& LiveliHood 81-2 (2006), http://www.fao.org/uploads/media/Reducing\%20poverty\%20through\%20community\%20 based\%20forest\%20management\%20in\%20Asia.pdf. See also Purnomo \& Anand, supra note 41, at 29.

105 Md Zahrul Muttaqin, Developing Community-Based Forest Ecosystem Service Management to Reduce Emissions from Deforestation and Forest Degradation, 108 Forest PoL'y \& Econ. 1 (2019), https://www.sciencedirect.com/ science/article/pii/S1389934118304659.

106 S. De Royer et al., Does Community-Based Forest Management in Indonesia Devolve Social Justice or Social Costs?, 20 InT'L Forestry REv. 172 (2018), https://doi.org/10.1505/146554818823767609.

107 M. Moeliono et al., Village Forests (Hutan Desa): Empowerment, Business or Burden? 2 (World Agroforestry Centre ed., 2015), https://www.cifor.org/knowledge/publication/5716.

108 Ahmad Dermawan, Decentralization in Indonesia's Forestry Sector: Is it Over? What Comes Next?, Paper presented at the Eleventh Biennial Global Conference of the International Association for the Study of Common Property (IASCP) on the "Survival of the Commons: Mounting Challenges and New Realities" (June 19-23, 2006), at 7, https://www. researchgate.net/publication/42760916_Decentralization_in_Indonesia\%27s_Forestry_Sector_Is_it_Over_What Comes_Next.

109 Ngo T.D. \& Mahdi, Targeting Deforestation Through Local Forest Governance in Indonesia and Vietnam, in 1 Redefining Diversity \& Dynamics of Natural Resources Management in Asia 273 (G. Shivakoti et al. eds., 2017), https://www.researchgate.net/publication/311995958_Targeting_Deforestation_Through_Local_Forest_Governance in_Indonesia_and_Vietnam. 
SFM. The low quality of human resources is also considered a factor in deforestation rates. ${ }^{110}$ As a result of the failures of CBFM, the Indonesian government established the Social Forestry Program to implement CBFM. The definition of social forestry according to Ministerial Decree 83/2016 of the Ministry of Environment and Forestry is as follows:

\begin{abstract}
Social forestry is a sustainable management system implemented in state forests or forest rights concessions/customary forests, undertaken by local communities or legal customary communities as the main stakeholders, in order to increase their prosperity, ensure environmental balance and social cultural dynamics, in the form of Village Forests, Community Managed Forests, Community Plantation Forests, Community Forests, Customary Forests, and Forestry Partnerships.
\end{abstract}

In this respect, the government's social forestry program encourages the community empowerment activities and community entrepreneurship, in addition to enhancing the prosperity of the community. ${ }^{111}$ In fact, the social, cultural, and belief-based systems of a community affect the implementation of social forestry. To develop these social forestry programs, the government provides communities with revolving loans to increase their access to capital and markets, as a means for achieving economic autonomy and enhanced community welfare. ${ }^{112}$ The financial support of the social forest is provided through national and local governance budgets, Village Funds, the Forest and Rehabilitation Fund, and other sources. ${ }^{113}$

Therefore, as a legal basis to encourage the active participation of the community in SFM and social forestry, the Indonesian government has already issued Presidential Regulation Number 16 Year 2015. ${ }^{114}$ The Indonesian government supports the formalization of customary forest ownership by communities. ${ }^{115}$ Based on the Constitutional Court Decision Number 35 Year 2012, the Indonesian government

110 R. Salahodjaev, Intelligence and Deforestation: International Data, 63 ForEst PoL'y \& ECON. 21 (2015), https://ideas. repec.org/a/eee/forpol/v63y2016icp20-27.html.

111 Agung ET AL., supra note 92, at 86.

112 See Indonesia Releases First Phase of EUR 6-Million Loan to Boost Sustainable Farming Based on IDH's Village Forest Model, IDH Sustainable Trade Initiative, Feb. 28, 2019, https://www.idhsustainabletrade.com/news/ indonesia-releases-first-phase-of-eur-6-million-loan-to-boost-sustainable-farming-based-on-idhs-village-forest-model.

113 Ida A. P. Resosudarmo et al., Indonesia's Land Reform: Implications for Local Livelihood and Climate Change, 108 Forest POL'Y \& ECON. 9 (2019), https://www.sciencedirect.com/science/article/pii/S1389934118303939.

114 J. Erbaugh, Responsibilization and social Forestry in Indonesia, 109 Forest POL'y \& ECON. 6 (2019), https://www. sciencedirect.com/science/article/pii/S1389934119303636.

115 A. Larson et al., Models for Formalizing Customary and Community Forest Lands: The Need to Integrate Livelihoods into Rights and Forest Conservation Goals, INFo BRIEF 2 (2019), https://www.cifor.org/knowledge/ publication/7273. 
recognizes the rights of communities to own and manage their forests in accordance with their customary laws. ${ }^{116}$ Activists and policymakers continue to develop new concepts and strategies focusing on the engagement of local communities in managing forest resources. ${ }^{117}$

The sustainability of forests is the responsibility of not only the government but also all stakeholders who are involved in forest exploitation. ${ }^{118}$ Forest management becomes the responsibility of the central government and local governments, although they try to improve preconditions for best forest practices as well as to enhance capacity building among the forest community. ${ }^{119}$ It includes biodiversity conservation and mitigating environmental damage through implementation of forest certification $^{120}$ and to achieve SFM.

\section{The Application of Forest Certification}

Historically, the concept of forest certification arose as a way to addressing public concerns about tropical deforestation and forest degradation. In early 1993, the cooperation among environmental NGOs and the coalition with the Worldwide Fund for Nature (WWF) established the Forest Stewardship Council (FSC). ${ }^{121}$ Massive deforestation and forest degradation in Indonesia are triggered by land conversion and illegal logging, ${ }^{122}$ which are difficult to overcome, although the Indonesian government has already issued many regulations and established new institutions to enforce the law in forestry.

To combat illegal logging, harmonise forest exploitation and forest protection, and enter the international market, the Indonesian government has finally

116 See A Turning Point for Indonesia's Indigenous Peoples, Bull. DTE (2013), https://www.downtoearth-indonesia. org/id/node/1025.

117 T. Santika, Community Forest Management in Indonesia: Avoided Deforestation in the Context of Anthropogenic and Climate Complexities, 46 Global Envtl. Change 61 (2017), https://www.sciencedirect.com/science/article/pii/ S0959378016305933.

118 D. Ruysschaert \& M. Hufty, Building an Effective Coalition to Improve Forest Policy: Lessons from the Coastal Tripa Peat Swamp Rainforest, Sumatra, Indonesia, 99 LANd UsE PoL’y 3 (2020), https://www.sciencedirect.com/ science/article/pii/S0264837716312698.

119 Yohan Lee et al., Measuring Social Capital in Indonesian Community Forest Management, 13(3) Forest SCI. \& TECH. 140 (2017), https://doi.org/10.1080/21580103.2017.1355335. See also Siscawati \& Zakaria, supra note 52, at 8.

120 P. Ellis et al., Reduced-Impact Logging for Climate Change Mitigation (RIL-C) can Halve Selective Logging Emissions from Tropical Forests, 438 Forest Ecology \& MGMt. 256 (2019), https://www.sciencedirect.com/ science/article/pii/S0378112718322126.

121 P. Perera \& R. Vlosky, A History of Forest Certification 3 (Louisiana Forest Products Dev. Ctr. Working Paper No. 71, 2006), https://pdfs.semanticscholar.org/da68/636d16a699a69d04602bf22c0c3e0686c913.pdf.

122 Tacconi et al., supra note 79 , at 8 . 
established certification schemes for timber production to implement SFM. ${ }^{123}$ Three certification schemes are applied in Indonesia. Two of them are voluntarily, namely the Indonesian Ecolabelling Institute or Lembaga Ekolabel Indonesia (LEI) and the Forest Stewardship Council (FSC), while the mandatory scheme is the Timber Legality Assurance System (TLAS) or Sistem Verivikasi Legalitas Kayu (SVLK). ${ }^{124}$

In June 2009, the Indonesian government set up the TLAS (or SVLK), as a mandatory certification to guarantee the legality of Indonesian timbers and reduce illegal logging. ${ }^{125}$ The TLAS was based on the Ministry of Forestry Regulation Number P.38/Menhut-II/2009 on the Standard for Evaluating Performance of Implementation of Sustainable Production Forest Management and Verification of Legality of Logs. ${ }^{126}$ Actually, forest certification is one of the economic instruments that can be instituted by the state to realize SFM. Forest certification is not only aimed to manage the forest in a sustainable manner, but also used as an economic instrument to take advantage of the forest. ${ }^{127}$ However, it is workable only when the Indonesian government exercises a mandatory certification scheme to encourage businesses and communities to participate in SFM.

Business entities holding the permit concessions contribute significantly to deforestation and forest degradation. Therefore, it is crucial to educate and encourage them to participate in SFM. The TLAS is a mandatory certification necessary for timber from Indonesia to have access to the European market. In the beginning, however, only a small number of the forest management units participated in

123 Sini Savilaakso et al., Timber Certification as a Catalyst for Change in Forest Governance in Cameroon, Indonesia, and Peru, 13(1) Int’L J. Biodiversity ScI, Ecosystem Services \& MGMt. 121 (2017), https://doi.org/10.1080/21513732. 2016.1269134. See also Dwi Rahmad Muhtaman, Forest Certification in Indonesia 12-3 (2004), https://www.academia. edu/6467595/Forest_Certification_in_Indonesia.

124 A. Wibowo \& L. Giessen, From Voluntary Private to Mandatory State Governance in Indonesian Forest Certification: Reclaiming Authority By Bureaucracies, 2(1) FOREST \& SOC'y 28-46 (2018), https://www.researchgate. net/publication/324789093_From_voluntary_private_to_mandatory_state_governance_in_Indonesian_forest_ certification_Reclaiming_authority_by_bureaucracies.

125 SUCOFINDO, First Annual Overview of the TLAS Operationality in Indonesia, Implementation, Report Periodic Evaluation FLEGT VPA-Indonesia European Union 17 (2018), https://www.euflegt.efi.int/documents/10180/438736/ Periodic+evaluation+Indonesia_final.pdf/ce95b6ef-aeae-2ec8-b600-cba756018780.

126 Santi Pratiwi et al., Third-Party Certification of Forest Management in Indonesia: Analysing Stakeholders' Recognition and Preferences, 21(2) J. Tropical Forest MGMt. 66 (2015), https://journal.ipb.ac.id/index.php/jmht/article/ view/10366/8082. See also Akiya Fishman \& Kristof Obidzinski, Verified Legal? Ramifications of the EU Timber Regulation and Indonesia's Voluntary Partnership Agreement for the Legality of Indonesian Timber, 17 INT'L FORESTRY REv. 11 (2015), https://www.cifor.org/knowledge/publication/5525.

127 Afiff Suraya et al., Toward Just and Sustainable Forestry in Indonesia: Lessons Learned from MFP3 EXPERIENCE IN SUPPORTING THE MoEF (2014-18) 71 (2014), https://silk.menlhk.go.id/app/Upload/repos/20190625/2 b5976ba1ae096fb4ac1fd33bce5be00.pdf. 
the certification process. ${ }^{128}$ The TLAS requires all timber in the supply chain to be harvested from sustainably managed forests as a compulsory requirement to obtain a Forest Law Enforcement, Governance and Trade Licensing Scheme (FLEG). ${ }^{129}$ However, the TLAS has not been successfully carried out due to the lack of auditing. ${ }^{130}$

It is mandatory for companies to obtain FLEG if they want to export their timber products to the European Union. Article 3 of the Voluntary Partnership Agreement (VPA) between Indonesia and the UK on Forest Law Enforcement states:

\begin{abstract}
A Forest Law Enforcement, Governance and Trade licensing scheme (hereinafter FLEGT Licensing Scheme) is hereby established between the Parties to this Agreement. It establishes a set of procedures and requirements aiming at verifying and attesting, by means of FLEGT licences, that timber products shipped to the Union were legally produced. In accordance with Council Regulation 2173/2005 of 20 December 2005, the Union shall only accept such shipments from Indonesia for import into the Union if they are covered by FLEGT licences.
\end{abstract}

Prior to the VPA, the Indonesian government was already prepared to comply with the requirement of the FLEGT licensing scheme by issuing the TLAS in 2009. The VPA Agreement was ratified by Indonesia and European Union in 2014 and came into force in the same year. ${ }^{131}$ Consequently, all timber products that are exported to the European Union have already obtained the TLAS. Hence, the TLAS as an economic and legal instrument is appropriate to affect the behaviour of companies to participate in SFM, since the FLEGT licencing scheme is designed to achieve SFM, as mentioned in the Preamble of the $\mathrm{VPA}^{132}$ as followed:

128 C. Purba et al., The State of The Forest Indonesia Period of 2009-2013, 36 (2014), https://programsetapak.org/ wp-content/uploads/2016/10/State-of-the-Forest-report-2009-2013.pdf.

129 M. Ya'kup Aiyub Kadir, Indonesian Timber Legality Assurance System (SVLK): In Pursuit of Sustainability in Forest Governance, 1 INDON. L. REv. 111 (2019), https://www.researchgate.net/publication/340556708_INDONESIAN_ TIMBER_LEGALITY_ASSURANCE_SYSTEM_SVLK_IN_PURSUIT_OF_SUSTAINABILITY_IN_FOREST_ GOVERNANCE. See also Anti Forest-Mafia CoAlition, SVLK Flawed: An Independent Evaluation of Indonesia's Timber Legality Certification System 36 (2014), https://d2d2tb15kqhejt.cloudfront.net/downloads/svlk_flawed_anti_ forest_mafia_coalition_report_on_svlk.pdf.

${ }_{130} \mathrm{Id}$.

131 EU FLEGT Facility, Q\&A Indonesia-EU Voluntary Partnership Agreement (2016), http://www.euflegt.efi.int/ q-and-a-indonesia.

132 "Voluntary Partnership Agreement between the United Kingdom of Great Britain and Northern Ireland and the Republic of Indonesia on Forest Law Enforcement, Governance and Trade in Timber Products into the United Kingdom of Great Britain and Northern Ireland," https://assets.publishing.service.gov.uk/government/uploads/system/ uploads/attachment_data/file/793433/CS_Indonesia_1.2019_VPA_Timber.pdf. 
... Recognising efforts by the Government of the Republic of Indonesia to promote good forestry governance, law enforcement and the trade in legal timber, including through the Sistem Verifikasi Legalitas Kayu (SVLK) as the Indonesian Timber Legality Assurance System (TLAS) which is developed through a multistakeholder process following the principles of good governance, credibility and representativeness; Recognising that the Indonesian TLAS is designed to ensure the legal compliance of all timber products; ...

Hence, the VPA between Indonesia and the UK has an important role in guaranteeing the trade of timber products from Indonesia legally under the forest governance.

According to the research conducted by Pratiwi and her team in 2015 regarding the recognition and preference of companies to use certification, the TLAS is the most preferable certification scheme due to its unsophisticated process and requirements if compared with the other voluntarily schemes recognized in Indonesia such as LEI and FSC. ${ }^{133}$ There are some reasons why companies favour the TLAS as follows:

(i) standards are suited to forest management practices in Indonesia; (ii) the requirements are easy to fulfil and understand; (iii) the government has made it mandatory; (iv) there are enough certification/verification bodies; and (v) the cost is low for the certification process and the availability of subsidies. ${ }^{134}$

The TLAS is more preferable than the other schemes because it is a requirement to obtain FLEG. Indeed, Indonesia has an obligation to implement TLAS as stipulated in Article 7 (1) of the VPA. Thus, the TLAS certification is compulsory for the companies, otherwise they will not be able to export timber products to the EU and will therefore lose their market. It can be acknowledged that the TLAS certification is an appropriate instrument to encourage companies to participate in SFM. If successful, the TLAS certification can be used as an economic instrument to realize SFM in Indonesia.

In 2016, the Indonesian government issued its FLEGT timber export licenses, ${ }^{135}$ which guarantee the approval of official institutional bodies for all Indonesia's certified timbers to enter the EU market. Indeed, FLEGT has fostered the credibility of Indonesia's timber products. However, it should be noted that challenges to the implementation of FLEGT still exist, such as timber laundering, "in which illegal

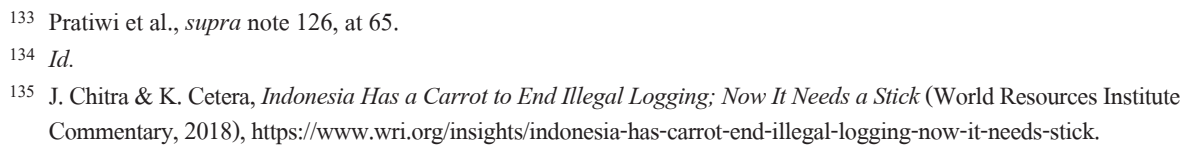


timber is mixed with legal timber and both are certified as legal."136

\section{Conclusion}

The PSNR principle entitles the state to control natural resources for the benefit of its people. SFM could not be achieved without active participation of the district governments, business authors, and communities, as well as the mechanism for strong law enforcement and harmonization of the conflicting regulations. The corruption affects law enforcement in Indonesia, thereby hampering the implementation of SFM. The Indonesian government has to struggle greatly to curb these problems. Accordingly, the government has initiated various efforts to overcome these challenges, such as strengthening law enforcement, conducting CBFM, and implementing mandatory certification for timber products to achieve SFM. The multidoor approach adopted in law enforcement in the forestry sectors is aimed to prevent perpetrators' escape from strict sanctions and to increase the deterring effects. However, the policy has not been successful yet. Instead, the TLAS as a mandatory certification system and a prior requirement of FLEGT licenses has already contributed to preventing and reducing illegal logging toward achieving SFM.

Unfortunately, the implementation of the PSNR principle in Indonesia has not been successful in balancing the PSNR principle and SFM. Therefore, the Indonesian government should strictly enforce the law in the forestry sector and enhance communities' capacity building as well as encourage business authors to participate in SFM. Additionally, the Indonesian government should harmonize the conflicting regulations to strengthen law enforcement and establish good coordination among the institutional bodies involved in law enforcement. Lastly, further work can be conducted for a better understanding in terms of balancing the implementation of the PSNR principle and SFM.

Received: August 1, 2021

Modified: October 1, 2021

Accepted: November 1, 2021

136 K. Cetera et al., Tracking Timber, Fighting Illegal Logging, (WRI Indonesia, 2018), https://wri-indonesia.org/en/ blog/tracking-timber-fighting-illegal-logging. 
